\section{Neoproterozoic carbon isotope positive anomalies: Primary or secondary? Global or regional?}

\author{
HUAN CUI $^{1,2}$, ALAN J KAUFMAN ${ }^{3}$, LUCAS VERÍSSIMO \\ WARREN $^{4}$, GABRIEL UHLEIN ${ }^{5}$, JULIANA OKUBO ${ }^{4}$ AND \\ XIAO-MING LIU $^{6}$ \\ ${ }^{1}$ Université de Paris \\ ${ }^{2}$ University of Toronto \\ ${ }^{3}$ University of Maryland \\ ${ }^{4}$ São Paulo State University (Unesp) \\ ${ }^{5}$ Federal University of Minas Gerais \\ ${ }^{6}$ University of North Carolina at Chapel Hill \\ Presenting Author: kaufman@umd.edu
}

The Neoproterozoic Era witnessed multiple episodes of positive carbon isotope excursions (CIEs) in bedded carbonates [1]. Notably, the Hüttenberg Formation in Namibia records a CIE with fluctuating values up to $+12 \%$ (aka the Hüttenberg anomaly). In addition, the Bambuí Group in Brazil records a positive CIE with a sustained plateau of ca. $+15 \%$ (aka the Middle Bambuí Excursion, MIBE). Understanding the origin of these positive CIEs is critical insofar as they have often been used as chemostratigraphic markers for correlation, and also as geochemical evidence for oceanic oxygenation.

Here, we established integrated $\delta^{13} \mathrm{C}_{\text {carb, }} \delta^{13} \mathrm{C}_{\text {org, }}$ and $\delta^{34} \mathrm{~S}_{\text {pyrite }}$ profiles for these two CIEs [2, 3]. Our data reveal covariation of $\delta^{13} \mathrm{C}_{\text {carb }}$ and $\delta^{13} \mathrm{C}_{\text {org }}$ in both events, which supports a depositional origin. In contrast, $\delta^{13} \mathrm{C}_{\text {carb }}$ and $\delta^{34} \mathrm{~S}_{\text {pyrite }}$ relationships are different in these two CIEs. The Hüttenberg Formation records an inverse $\delta^{13} \mathrm{C}-\delta^{34} \mathrm{~S}$ relationship over nearly a kilometer of section, with the $\delta^{13} \mathrm{C}_{\text {carb }}$ values rising from $+2 \%$ to $+12 \%$ and back again in concert with $\delta^{34} \mathrm{~S}_{\text {pyrite }}$ values plunging from ca. $+40 \%$ to ca. $-10 \%$ and then returning to ca. $+30 \%$ [2]. In contrast, the MIBE plateau is characterized by both higher $\delta^{13} \mathrm{C}_{\text {carb }}$ (up to $+14 \%$ ) and higher $\delta^{34} \mathrm{~S}_{\text {pyrite }}$ (up to $+30 \%$ ) values compared with the MIBE recovery interval (mean $\delta^{13} \mathrm{C}_{\text {carb }}$ $+7.5 \%$; mean $\delta^{34} \mathrm{~S}_{\text {pyrite }}+13.7 \%$ ) [3].

These contrasting $\delta^{13} \mathrm{C}-\delta^{34} \mathrm{~S}$ relationships suggest the effects of different biogeochemical $\mathrm{C}$ and $\mathrm{S}$ cycles during these two CIEs. The Hüttenberg anomaly likely records an oxygenation event during the height of the CIE, and a deoxygenation event at its termination. The $\delta^{34} \mathrm{~S}_{\text {pyrite }}$ trend suggests a transient increase in marine sulfate reservoir, followed by a sulfate drawdown at the end.

The MIBE may reflect a different scenario. We regard that enhanced organic carbon burial alone is insufficient to explain the extreme ${ }^{13} \mathrm{C}$ enrichment. Instead, regional controlling factors, including water-column methanogenesis or low sulfate availability (evidence by higher $\delta^{34} \mathrm{~S}_{\text {pyrite }}$ ) in a semi-restricted basin could have played a role in enhancing the CIE.

References:

1. Kaufman et al., 1997. PNAS, 94, 6600-6605.

2. Cui et al., 2018. Precambrian Research, 313, 242-262. 